\title{
THE STOCK RETURN PREDICTABILITY: COMPARING P/E AND EV/EBITDA
}

\section{DOI: 10.17261/Pressacademia.2017.694}

JEFA- V.4-ISS.3-2017(6)-p.262-274

\section{Yuksel Iltas ${ }^{1}$, Halil Arslan ${ }^{2}$, Temur Kayhan ${ }^{3}$}

Ahi Evran University, Faculty of Economics and Administrative Sciences, Kırşehir, Turkey. iltasyuksel@gmail.com

İstanbul Şehir University, Faculty of Economics and Administrative Sciences, İstanbul, Turkey. halilarslan4444@gmail.com

istanbul Şehir University, Faculty of Economics and Administrative Sciences, ìstanbul, Turkey. kayhantemur44@gmail.com

To cite this document

Iltas, Y., Arslan, H. and Kaynah, T., (2017). The stock return predictability: comparing P/E and EV/EBITDA. Journal of Economics, Finance and Accounting (JEFA), V.4, Iss.3, p.262-274.

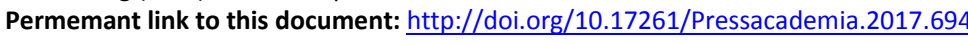

Copyright: Published by PressAcademia and limited licenced re-use rights only.

\begin{abstract}
Purpose - The aim of this work is to pinpoint the association between stock retuns and financial dynamics, market dynamics and regional and firm-specific uncertainties. While dividend yield, P/E, EV/EBITDA, P/B, Investment Ratio, Leverage, Intangible Assets, Topline Growth, Country Risk, Standard Deviation, Geopolitical Uncertainties, and Liquidity are taken into consideration as factors affecting stock returuns, lagged value of dependent variable is also accepted as independent variable.

Methodology- All the equations are figured out by Generalized Method of Moments (GMM) while 2.549 data of 204 companies from 24 sectors traded at BIST between 1998-2014 are used in the study.

Findings- According to the outcomes of the model, the rise in Expected Dividend Yield, Investment Ratio, Sales Growth and Liquidity influence positively stock returns, whereas the uptrend in geopolitical risks, country risks, company specific risks and intangible investments affect the stock returns negatively. The decline in $\mathrm{P} / \mathrm{E}$ and EV/EBITDA increases stock returns.

Conclusion- In addition to the increase in net profit, investment, dividend and sales, firms can ramp up their corporate value by using liquidity provider operations and augmenting free float ratios, and they can leverage the value in their operational activities. Also, while investors pay close attention to $\mathrm{P} / \mathrm{E}$ and EV/EBITDA multiples simultaneously, investment maturity of them are about 1 year.
\end{abstract}

Keywords: P/E, EV/EBITDA, stock return, liquidity, dividend yield.

JEL Codes: L25, B41, G30

\section{HISSE GETIRILERININ MODELLENMESI: F/K \& FD/FAVÖK KIYASLAMASI}

\section{ÖZET}

Amaç- Bu çalışmanın amacı hisse senedi getirileri ile finansal dinamikler, piyasa dinamikleri ve bölgesel ve şirketlere özgü riskler arasındaki ilişkiyi belirlemektir. Hisse getirisini etkileyen faktörler olarak Temettü Verimi, F/K, FD/FAVÖK, PD/DD, Yatırım Oranı, Kaldıraç Oranı, Maddi Olmayan Yatırım Oranı, Satış Büyümesi, Ülke Riski, Standart Sapma, Jeopolitik Riskler ve Likidite belirlenirken hisselerin bir önceki getiri seviyelerinden de etkilendiği varsayılmıştır.

Yöntem - BisT’de 1998-2014 arasında işlem gören 24 sektörden 204 şirketin 2,549 verisi çalışmada kullanılırken tüm denklemler Genelleştirilmiş Momentler Metodu (GMM) ile çözümlenmiştir.

Bulgular- Çalışmadan elde edilen bulgulara göre beklenen temettü verimi, yatırım oranı, satış büyümesi ve likiditeki artış hisse getirilerini olumlu etkilerken jeopolitik riskler, ülke riski, şirkete özgü riskler ve maddi olmayan yatırımlardaki artış getirileri düşürmektedir. $\mathrm{F} / \mathrm{K}$ ve FD/FAVÖK'deki gerileme ise hisse getirilerini artırmaktadır.

Sonuç- Şirketler yatırımcılarda beklenti oluşturan net kar, yatırım, temettü ve satışlardaki artışa ek olarak likidite sağlayıcılık işlemleri ve halka açıklık oranlarını artırarak şirket değerlerini yükseltebilir ve söz konusu değeri operasyonel faaliyetlerinde kaldıraç olarak kullanabilirler. Ayrıca yatırımcılar F/K ile FD/FAVÖK çarpanlarına neredeyse eşit oranda önem verirken yatırım vadeleri yaklaşık 1 yıldır.

Anahtar Kelimeler: F/K, FD/FAVÖK, hisse getirisi, likidite, temettü verimi.

JEL Kodları: L25, B41, G30 


\section{GiRiş}

Hisse senedi getirilerinin modellenmesi son dönemde önemi artan çalışmalar arasında yer almaktadır. Hisse senedi getirilerinin GSYiH büyümesi, enflasyon ve işsizlik gibi makroekonomik değişkenler üzerinde etkileri olduğuna yönelik bulguların elde edilmesi merkez bankalarının uzun vadeli politikalarının belirlenmesinde hisse senedi piyasasındaki değişimlerin de etkili olabileceğine dair görüşleri kuvvetlendirmektedir.

Türkiye örneği için gerçekleştirdiğimiz çalışmada elde ettiğimiz sonuçlara göre piyasadaki genel algının aksine BisT yatırımcıları F/K' ya FD/FAVÖK kadar önem vermekte; iki çarpanın eşanlı etkisi hisse getirisini etkilemekte ve ortalama vade yaklaşık 1 yıl olarak hedeflenmektedir. Bu durum yatırımcıların değerlemede iki önemli çarpanı dikkate aldığı anlamına gelirken ortalama vadenin sanılanın aksine kısa dönemli olmadığını da göstermektedir. Elde ettiğimiz sonuçlara göre hisse senetleri diğer tüm değişkenler sabitken ortalamada bir önceki yılki getirilerin tersine bir eğilimdedirler.

Gelişmekte olan ülkeler için geçerli bir algı olan temettü dağıtma yerine yatırım yapma eğiliminin tersine Türk hisse senedi piyasasında temettü beklentisi yükseldikçe hisse getirilerde önemli bir artı̧̧ gözlenmektedir. Beklentiye odaklı bir diğer çıkarım ise yıl içerisindeki sabit sermaye yatırımları ve satış büyümesinin hisse getirisini olumlu etkilemesidir. Ancak şirketlerin stratejik yatırımlarında sınıflandırılan maddi olmayan varlık yatırımları gerekli nitelikte olmadığı ve riskli yatırımlar sınıfında yer alması nedeniyle hisse getirisinde beklenen etkiye sahip değildir.

Elde ettiğimiz sonuçlara göre şirketler stratejik hedeflerine likidite sağlayıcılık ve halka açıklığın artırılmasını da eklemeli ve likiditeden kaynaklı şirket değerini artırmalıdırlar. ABD'de şirketler, oldukça yüksek halka açıklık oranları ile şirket değerlerini güçlendirmekte ve artan şirket değerini operasyonel faaliyetlerinde kaldıraç olarak kullanmaktadırlar. Son olarak jeopolitik riskler, ülke riski ve şirketlere özgü risklerin hisse getirisinde önemli etkileri olduğu tespit edilmiştir.

Çalışmamızın literatüre farklı alanlarda katkıları olduğunu düşünmekteyiz. Öncelikle hisse getiri modellemesi Türkiye örneğinde cari verilerle test edilmiş ve çalışmanın kapsamında kullanılan veri sayısı sonuçların güvenilirliği açısından literatüre katkı sağlayacak boyuttadır. Literatürde genellikle hisse getirilerinin F/K ve PD/DD gibi oranlardan etkilendiği ifade edilirken birçok uluslararası ve yerel birleşme ve satın almalarda tercih edilme oranı yüksek ve piyasadaki danışmanlarca en çok kullanılan oranlardan biri olan FD/FAVÖK değerleme çarpanı modelimize eklenmiştir. FD/FAVÖK ve F/K çarpım değişkeni ile Türk piyasası yatırımcılarının piyasa çarpanlarına çok boyutlu bakışı test edilmiştir. Ayrıca jeopolitik ve şirketlere özgü risklerin hisse getirisinde finansal veriler kadar etkisi olduğu dikkate alınarak söz konusu değişkenler modelimizde yer almıştır. Maddi olmayan varlıklar ile sabit sermaye varlıklarının ayrı ayrı etkisi gösterilmeye çalışılırken hisse senedi getirilerinin bir önceki getiri seviyesinden etkilendiği varsayımı literatüre bir diğer katkı olarak düşünülebilir.

Çalışmanın geri kalanı şu şekildedir: Girişi izleyen ikinci bölümde ilgili literatür verilecektir. Üçüncü bölümde model, değişkenler ve veri seti tanıtılacaktır. Dördüncü bölüm, GMM regresyon bulgularının sunulmasına ayrılmıştır. Çalışmanın beşinci bölümü olan sonuç bölümünde ise, bulgular özet olarak verilecek ve tartışılacaktır.

\section{LITERATÜR INCELEMESi}

Literatürde finansal performansı ölçmeye yönelik birçok çalışma yapılmıştır. Yapılan çalışmaların bir kısmında hisse senedi getirileri ile muhasebe temelli performans ölçütleri ilişkilendirilirken, bazılarında değer temelli performans ölçütlerinin hisse getirisine etkisi incelenmiştir. Her iki performans ölçütünün birlikte kullanıldığı çalışmalar da literatürde yer almaktadır.

Hisse senedi getirilerini tahmin etmede birçok finansal oranın (finansal ölçüt) getiri ile ilişkisi üzerinden hareket edilmiştir. Hisse senedi getiri tahmininde kullanılan finansal oranların; piyasa değeri/defter değeri (PD/DD), borç/özsermaye oranı, fiyat/kazanç oranı (F/K), likidite, kârlılık ve sermaye yapısı oranları olduğu tespit edilmiştir. (Holthausen ve Larcker, 1992; Mukherji vd., 1997; Aktaş ve Karan, 2000; Lewellen, 2002; Canbaş, Düzakın ve Kılıç, 2002; Omran ve Ragab, 2004; Korkmaz ve Karaca, 2013). Çalışmalarda finansal ölçütlerin hisse senedi getirilerini açıklamada çok güçlü bir açıklama gücüne sahip olduğu ifade edilmiştir. Ayrıca fiyat/kazanç oranı ile birlikte nakit oran ve toplam varlık devir hızı oranı modele eklendiğinde açıklama gücünün arttığı ve dolayısıyla önemli birer bağımsız değişken olduğu da tespit edilmiştir (Ege ve Bayrakdaroğlu, 2009).

Literatürde hisse senedi getirileriyle fiyat/kazanç oranı arasındaki ilişkiyi araştıran birçok çalışma yapılmış olup farklı sonuçlar elde edilmiştir. Bu çalışmaların bazılarında hisse senedi getirileriyle fiyat/kazanç oranı arasında istatistiksel olarak anlamlı ilişki tespit edilemezken (Mukherji vd., 1997; Demir vd., 1996); kimi çalışmalarda fiyat/kazanç oranı etkisinin istatistiksel olarak anlamlı bir düzeyde olduğu ortaya konmuştur. (Basu, 1977; Karan, 1996; Lewellen, 2002; Chang, 2008; Horasan, 2009). Konuya ilişkin bazı ampirik çalışmalarda hisse senedi fiyatlarının uzun dönemde ve ortalamada firma varlık değerleriyle birlikte hareket ettiği belirlenmiştir. (Campbell ve Shiller, 1998; Oh, Kim ve Kim, 2006).

Kâr payı dağıtım politikası ile hisse senedi fiyat değişimleri arasındaki ilişkinin incelendiği çalışmalarda farklı sonuçlar elde edilmiştir. Yıllık hisse senedi getirilerinin bağımlı değişken olarak kullanıldığı çalışmalarda toplam varlık devir hızı, hisse başına kârdaki değişim, kâr marjı, aktif kârlııı, özsermaye kârlıı̆̆ı, satışlardaki kârlııı, temettü verimi ve vergi sonrası kâr 
gibi değişkenler bağımsız değişken olarak kullanılmıştır (Şamiloğlu, 2005; Dehaun ve Jin, 2008; Moderes vd., 2008; Okafor vd., 2011; Khan vd., 2011; Habib vd., 2012; Korkmaz ve Karaca, 2013). Çalışmaların bazılarında belirtilen bağımsız değişkenlerin hisse senedi fiyatı ile pozitif yönlü olarak ilişkili olduğu (Moderes vd., 2008; Khan vd., 2011) tespit edilirken, Dehaun ve Jin (2008) tarafından yapılmış olan çalışmada bağımsız değişkenlerin açıklanan dönemin sadece ilk iki döneminde hisse senedi getirisini etkilediği ifade edilmiştir. Okafor, Mgbame ve Chijoke (2011) tarafından yapılan çalışmada temettü veriminin hisse senedi fiyatı üzerinde negatif yönlü bir etkiye, kâr payı dağıtım oranının ise bazı yıllarda negatif bazı yıllarda ise pozitif bir etkiye sahip olduğu ortaya konmuştur. Ancak Habib, Zernigah ve Muhammad (2012) tarafından yapılan çalışmada hisse senedi fiyatı ile temettü verimi arasında pozitif yönlü ilişki, kâr payı ödeme oranıyla negatif ilişki bulunmuştur.

Konuya ilişkin bazı ampirik çalışmalarda hisse ve nakit temettünün hisse senedi fiyatına etkisi araştırımıştır (Batchelor ve Orakcıoğlu,2003; Günalp, Kadıoğlu ve Kılıç, 2010). Nakit ödeme günü olay günü olarak alınan çalışmada, nakit temettü açıklanmasının fiyat üzerinde etkisinin olduğuna dair bulgulara ulaşılamamıştır. (Batchelor ve Orakcıoğlu,2003). Günalp vd. (2010) tarafından yapılan çalışmada ise nakit temettünün açıklanması sonrasında hisse başına nakit temettü oranı ile kümülatif normalüstü getiri arasında istatistiksel olarak anlamlı ve negatif yönlü bir ilişkinin varlığı ortaya konmuştur.

Literatürde hisse senedi getirileri ile finansal performans ölçütleri arasındaki ilişkiyi araştıran birçok çalışmanın yapıldıı̆ı görülmektedir. Ancak literatür incelmesinde özetlenen çalışmalardan da anlaşılacağı üzere hisse senedi getirileri ile gerek muhasebe temelli gerekse değer temelli finansal performans ölçütleri arasında farklı sonuçlar ortaya konmuştur. Literatürdeki çalışmalarda farklı sonuçların elde edilmesi ölçütlerin metodolojilerinin aynı olmaması ile açıklanabileceği gibi kullanılan veri setinin içeriği ve dönemi de bu durumda etkili olmuş olabilir. Dolayısıyla daha çok teorik ve uygulamalı çalışmalar yaparak bu konu hakkında daha net yorumlarda bulunmak mümkün olacaktır.

\section{MODEL, DEĞişKENLER VE VERI SETi}

Çalışmanın bu bölümünde öncelikle oluşturulan modele, model kapsamındaki değişkenlere ve veri setine değinilmektedir. Sonrasında ise çalışmada kullanılan ve Arellano (1991) tarafından geliştirilmiş GMM yöntemi ile elde edilen ampirik bulgular verilmektedir.

\subsection{Model}

Veri sayısını artırmak ve yatırımcıların ortalama davranıs modelini belirleyebilmek adına çalışmamızda panel veri seti kullanılmıştır. Başka bir deyişle birey kesitlerin zaman serileri veri setini oluşturmaktadır. Bu durum hem zamanın hem de farklılaşmayı beraberinde getiren farklı birey kesitlerin, hisse getirilerinin modellenmesinde etkisi olduğu anlamına gelmektedir. Birçok ekonomik ilişkinin dinamik olduğu varsayılmaktadır ki bu durum bağımlı değişkenin gecikmeli değerinden etkilenmesi olarak tanımlanmaktadır. Modeldeki temel varsayımımız hisse senedi getirilerinin gecikmeli değerinden etkilendiği yönündedir. Borsa yatırımcıları ve profesyonelleri arasında tek yıl-çift yıl kavramının yerleşmiş olması varsayımımızı teyit etmektedir. Bu durum modelimizde bağımsız değişkenler arasında bağımlı değişkenin gecikmeli değerinin olmasını beraberinde getirmektedir. Böylece panel veri modelimiz dinamik modele dönüşmektedir. Literatürde tüm dinamik panel veri seti Genelleştirilmiş Momentler Metodu (GMM) ile analiz edilmektedir.

(Baltagi, 2005)'ya göre dinamik panel veri setinde EKK (OLS)'nın kullanılması yanlı ve tutarsız katsayılar üretecektir. Bu durum (Arellano, 1991) tarafından geliştirilmiş GMM'nin doğmasının en büyük nedenidir. GMM yüksek seviyede istatistik modeli olarak tanımlanmakta ve EKK'nın üst versiyonu olarak görülmektedir. Ayrıca ekonomik ilişkilerin dinamik yapısına (gecikmeli değerden etkilenme) daha uygun bir modeldir.

Panelin doğası gereği veri seti, farklılaşabilmektedir. Heterojen Yapı söz konusu farklılaşma modelde yer almadığı halde hata teriminde yer alan ve bağımlı değişkeni etkilediği gibi birey kesitten birey kesite değişen faktörlerin var olmasını beraberinde gerektirmektedir. Zira söz konusu değişkenler hata teriminde yer aldığı halde bağımsız değişkenlerle ilişkili olabilir ve içsellik (endojenlik) problemi doğurabilirler. Bu durum zamandan bağımsız birey kesitten birey kesite değişen faktörlerin yok edilmesini gerektirmektedir. Örneğin şirketlerin farklı iklim koşullarında faaliyet göstermeleri modelde yer almadığı halde şirketlerin hisse getirilerini etkileyebilen ve modelde hata teriminde yer alan bir faktördür. Söz konusu değişkenler bağımsız değişkenlerle bağlantılı olabileceği gibi zamandan bağımsızdırlar. Bu durumu GMM, birinci dereceden farklar ile düzeltmektedir. Denklemin bir önceki serisinden farkı alındı̆̆ında zamana göre değişmeyen bireysel etkiler yok olmakta ve içsellik problemi çözülmektedir. Birinci dereceden farklar, GMM modellerinde durağanlık ve yatay kesit bağımlıı̆̆ı problemini de çözer. Literatürde GMM modellerinde genellikle durağanlık testinin ölçülmemesinin en önemli nedenlerinden birisi de budur.

Her ne kadar GMM birinci dereceden farklar ile kısmen içsellik problemini çözse de birey kesit etkilerin zamana göre değişen boyutları da olabilmektedir. Ayrıca denklemde gecikmeli bağımlı değişkenin olması içsellik probleminin tamamen yok edilmesinde önemli bir etkendir. Bu yüzden GMM, birinci dereceden farklar sonrasında içselliği tamamen yok etmek için bağımsız değişkenlerle ilişkili hata terimi ile ilişkisiz enstrüman değişkenler kullanır. Söz konusu değişkenler için en büyük 
aday ana modeldeki bağımsız değişkenler ve gecikmeli bağımlı değişkenin gecikmeli değerleridir. Böylece GMM içsellik problemini tamamen ortadan kaldırmış olur.

Ana model;

$$
y_{i t}=a_{i}+\varphi y_{i, t-1}+\beta \text { Piyasa Çarpanlart } t+\psi X_{t}+u_{i t}
$$

$$
\begin{gathered}
H G_{i t}=a_{i}+\beta_{1} H G_{i, t-1}+\beta_{2}\left(F D / F A V O ̈ K_{i t}\right)+\beta_{3}\left(F / K_{i t}\right)+\beta_{4}\left(F / K_{i t}\right)\left(F D / F A V O ̈ K_{i t}\right)+\beta_{5} T V_{i t}+ \\
\beta_{6} J P R_{t}+\beta_{7} \text { Yatırım }_{i t}+\beta_{8} \text { Kaldıraçit }_{i t}+\beta_{9}\left(P D / D D_{i t}\right)+\beta_{10} \text { Tobin }_{i t}+\beta_{11} \text { Tahvil }_{t}+\beta_{12} S B_{i t}+\beta_{13} \text { Std }_{i t}+ \\
\beta_{14} \text { Likidite }_{i t}+u_{i t}
\end{gathered}
$$

$y_{i t}$ hisse senetlerinin yıllık getirisini sembolize etmektedir. $a_{i}$ birey kesitlerden birey kesitlere göre farklılaşan ancak zamana göre değişmeyen sabit etkileri gösterirken $X_{t}$ kontrol değişkenler vektörüdür.

\subsection{Değişkenler}

\begin{tabular}{|c|c|c|c|}
\hline Kod & Değişken & Açıklama & Dönemi \\
\hline HG & Hisse Getirisi & 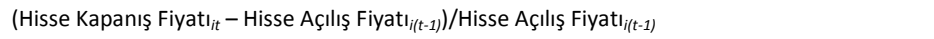 & $1998-2014$ \\
\hline TV & Temettü Verimi & Yıl İçerisinde Dağıtılan Brüt Temettü & 1998-2014 \\
\hline $\mathrm{F} / \mathrm{K}$ & Fiyat/Kazanç Oranı & Bilanço Dönemindeki Ortalama Piyasa Değeri ${ }_{i t} /$ Ana Ortaklık Kârl ${ }_{i(t-1)}$ & $1998-2014$ \\
\hline FD/FAVÖK & \begin{tabular}{|l|} 
Firma \\
Değeri/FAVÖK
\end{tabular} & Bilanço Dönemindeki Ortalama Firma Değeri $i_{i t} /$ FAVÖK $_{i(t-1)}$ & $1998-2014$ \\
\hline JPR & $\begin{array}{l}\text { Jeopolitik Risk } \\
\text { (JPR) Türkiye } \\
\end{array}$ & Türkiye Jeopolitik Risk Endeksi $t_{t}$ & $1998-2014$ \\
\hline Yatırım & Yatırım Oranı & Yıl içeresindeki Toplam Yatırım ${ }_{i t} / Y_{ı} l$ Sonu Aktif ${ }_{i t}$ & $1998-2014$ \\
\hline Kaldıraç & Kaldıraç Oranı & Yıl İçerisindeki Ortalama Finansal Borçit/ $/ Y_{\text {Il }}$ İçerisindeki Ortalama Aktif ${ }_{i t}$ & $1998-2014$ \\
\hline $\mathrm{PD} / \mathrm{DD}$ & \begin{tabular}{|l} 
Piyasa Değeri/ \\
Defter Değeri \\
\end{tabular} & 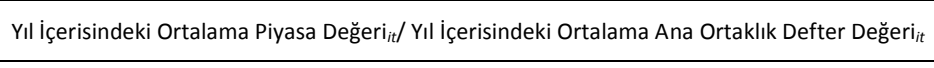 & 1998-2014 \\
\hline Tobin Q & Tobin Q & Yıl İçerisindeki Ortalama Firma Değeri ${ }_{i t} / Y_{ı}$ I İçerisindeki Ortalama Aktifler ${ }_{i t}$ & $1998-2014$ \\
\hline Tahvil & \begin{tabular}{|l} 
Gösterge Tahvili \\
(Ülke Riski) \\
\end{tabular} & Gösterge Tahvili Faizi $t_{t}$ & 1998-2014 \\
\hline SB & Satı̧̧ Büyümesi & $\left(\right.$ Net Satışlar $_{i t}-$ Net satışlar $\left._{i(t-1)}\right) /$ Net satışlar ${ }_{i(t-1)}$ & $1998-2014$ \\
\hline Std & Standard Sapma & Hisse Senedi Getirilerinin Standart Sapmasl ${ }_{i t}$ & 1998-2014 \\
\hline Likidite & Likidite Oranı & Yıl İçerisindeki Ortalama Günlük İşlem Hacmi ${ }_{i t} / Y_{\text {II }}$ Ortasındaki Halka Açık Piyasa Değeri ${ }_{i t}$ & 1998-2014 \\
\hline
\end{tabular}

Çalışmada kullanılan değişkenlere ilişkin bilgiler Tablo 1'de özetlenmiştir. Ayrıca Ek-1'de, değişkenlerin 1998-2014 dönemine ait yıllık ortalama verilerinin grafikleri gösterilmiştir.

Tablo 1: Çalışmada Kullanılan Değişkenler

Her bir yılın başındaki dönem olan Ocak-Nisan ayında bir önceki yılın bilançosu açıklanmakta ve piyasa söz konusu bilançoyu fiyatlamaktadır. Her bir yılın sonunda gerçekleşen hisse senedi getirilerinin bir önceki yıl bilanço döneminde oluşan F/K'lardan etkilendiği varsayılmıştır. Yani yılın ilk çeyreğindeki F/K yılsonu getiriler için bir referans olarak kabul edilmiştir. Her bir yıl için yılın 1 Ocak- 1 Nisan dönemindeki ortalama piyasa değeri o tarihte açıklanmış olan son yıllık ana ortaklık karına bölünmüş; ve $\mathrm{F} / \mathrm{K}$ değerleri hesaplanmıştır.

Benzer yaklaşım ile her bir yılın sonunda gerçekleşen hisse senedi getirilerinin bir önceki yıl bilanço döneminde oluşan FD/FAVÖK'lerden etkilendiği varsayılmıştır. Yani yııın ilk çeyreğindeki FD/FAVÖK yılsonu getiriler için bir referans olarak kabul edilmiştir. Her bir yıl için yılın 1 Ocak- 1 Nisan dönemindeki ortalama firma değeri o tarihte açıklanmış olan son yıllık faiz amortisman vergi öncesi kar bölünmüş; ve FD/FAVÖK değerleri hesaplanmıştır.

\subsection{Veri Seti}

Çalışmada Borsa İstanbul'da 1998-2014 arasında işlem gören 24 sektörden 204 şirketin 2,549 firma-yıl verisi kullanılmıştır. Ülke riskini ölçme amaçlı en aktif devlet tahvilinin aynı dönemlerdeki faizi kullanılırken Türkiye Jeopolitik Risk endeksinin söz konusu dönemdeki verisi de modele dâhil edilmiştir. Şirketlere ait veriler firmaların yıllık ve ara dönem bağımsız denetim 
raporları, faaliyet raporları, Bloomberg ve Finnet veri sağlayıcıdan elde edilirken Jeopolitik Risk Endeksi, Economic Policy Uncertainity Group ${ }^{1 \prime} \tan$ sağlanmıştır.

Bazı istisnalar dışında incelenen dönem boyunca 30 milyon TL aktif ve \%5 halka açıklık oranına ulaşamayan şirketler örneklemden çıkarılmıştır. En az 3 yıl verisi olmayan şirketler, verinin devamlılı̆ı için birkaç istisna hariç örneklemden çıkarılmıştır. Böylece olabildiğince verimli piyasa fiyatlamasına ulaşılmaya çalışılmıştır. İşlem hacmi düşük firmaların örneklemde baskın olması halinde söz konusu hisselerin fiyatlamasının piyasada pek de sağlıklı olmaması nedeniyle yanlı ve tutarsız katsayılar elde edilebilir. Tablo 2' de BiST'te 1998-2014 arasında işlem gören 204 şirketin sektörel dağılımı verilmiştir.

Tablo 2: Firmaların Sektörel Dağılımı

\begin{tabular}{|c|c|c|c|c|}
\hline Sektör & Firma-Yıl Verisi & Oran & Firma Sayısı & Oran \\
\hline Ambalaj & 81 & $3,2 \%$ & 6 & $2,9 \%$ \\
\hline Basın-Medya & 79 & $3,1 \%$ & 9 & $4,4 \%$ \\
\hline Dayanıklı Tüketim & 123 & $4,8 \%$ & 8 & $3,9 \%$ \\
\hline Boru-Kablo & 131 & $5,1 \%$ & 9 & $4,4 \%$ \\
\hline Boya & 49 & $1,9 \%$ & 3 & $1,5 \%$ \\
\hline Cam & 81 & $3,2 \%$ & 5 & $2,5 \%$ \\
\hline Çimento & 221 & $8,7 \%$ & 14 & $6,9 \%$ \\
\hline Demir Çelik & 83 & $3,3 \%$ & 5 & $2,5 \%$ \\
\hline Enerji & 48 & $1,9 \%$ & 6 & $2,9 \%$ \\
\hline Gıda & 248 & $9,7 \%$ & 20 & $9,8 \%$ \\
\hline Gübre & 67 & $2,6 \%$ & 4 & $2,0 \%$ \\
\hline İçecek & 73 & $2,9 \%$ & 5 & $2,5 \%$ \\
\hline İnşaat-Taahhüt & 64 & $2,5 \%$ & 7 & $3,4 \%$ \\
\hline Kâğıt & 65 & $2,6 \%$ & 4 & $2,0 \%$ \\
\hline Madencilik & 42 & $1,6 \%$ & 5 & $2,5 \%$ \\
\hline Mobilya & 42 & $1,6 \%$ & 3 & $1,5 \%$ \\
\hline Turizm & 111 & $4,4 \%$ & 9 & $4,4 \%$ \\
\hline Otomotiv ve Yan Sanayii & 205 & $8,0 \%$ & 16 & $7,8 \%$ \\
\hline Perakende Ticaret & 87 & $3,4 \%$ & 12 & $5,9 \%$ \\
\hline Petrokimya & 131 & $5,1 \%$ & 8 & $3,9 \%$ \\
\hline Teknoloji Toptancısı & 57 & $2,2 \%$ & 6 & $2,9 \%$ \\
\hline Tekstil & 322 & $12,6 \%$ & 25 & $12,3 \%$ \\
\hline Telekom ve Bilişim & 84 & $3,3 \%$ & 8 & $3,9 \%$ \\
\hline Ulaşım ve Nakliye & 55 & $2,2 \%$ & 7 & $3,4 \%$ \\
\hline Tüm Sektörler & 2.549 & $100,0 \%$ & 204 & $100 \%$ \\
\hline
\end{tabular}

Not: Makalede BiST'te 1998-2014 arasında işlem gören 24 sektörden 204 şirketin 2.549 verisi analiz edilmiştir.

Çalışmada kullanılan bağımlı değişken ve bağımsız değişkenlere ilişkin ortalama, standart sapma ve korelasyon matrisi şekil 1 'de sunulmuştur.

\footnotetext{
${ }^{1}$ http://www.policyuncertainty.com/
} 
Şekil 1: Ortalama, Standart Sapma ve Korelasyonlar

\begin{tabular}{|c|c|c|c|c|c|c|c|c|c|c|c|c|c|c|c|c|}
\hline \multirow{2}{*}{\multicolumn{2}{|c|}{$\begin{array}{l}\text { Değişken } \\
\text { Tüm Örneklem }\end{array}$}} & \multicolumn{2}{|c|}{ Medyan Ortalama } & \multicolumn{13}{|c|}{ S.S. Korelasyonlar } \\
\hline & & & & & 1 & 2 & 3 & 4 & 5 & 6 & 7 & 8 & 9 & 10 & 11 & 12 \\
\hline 1 & Hisse Getirisi & 0,148 & 0,417 & 1,145 & 1,000 & & & & & & & & & & & \\
\hline 2 & Temettü Verimi & 0,000 & 0,024 & 0,042 & $-0,035$ & 1,000 & & & & & & & & & & \\
\hline 3 & $\mathrm{~F} / \mathrm{K}$ & 8,41 & 25,68 & 403,80 & $-0,020$ & $-0,012$ & 1,000 & & & & & & & & & \\
\hline 4 & Jeopolitik Risk & 69,4 & 88,5 & 41,4 & $-0,064$ & 0,015 & $-0,038$ & 1,000 & & & & & & & & \\
\hline 5 & Yatırım Oranı & 0,082 & 0,185 & 0,518 & 0,040 & 0,001 & 0,000 & 0,162 & 1,000 & & & & & & & \\
\hline 6 & Kaldıraç Oranı & 0,207 & 0,265 & 0,356 & $-0,043$ & $-0,165$ & 0,003 & 0,025 & $-0,011$ & 1,000 & & & & & & \\
\hline 7 & PD/DD & 1,36 & 2,39 & 21,61 & 0,027 & $-0,016$ & $-0,001$ & 0,005 & $-0,001$ & 0,007 & 1,000 & & & & & \\
\hline 8 & Maddi OImayan Varlıklar & 0,836 & 1,033 & 1,261 & 0,057 & $-0,027$ & 0,008 & $-0,105$ & 0,008 & 0,151 & 0,093 & 1,000 & & & & \\
\hline 9 & Ülke Riski & 0,165 & 0,270 & 0,292 & 0,007 & 0,091 & 0,019 & 0,109 & 0,212 & 0,010 & 0,047 & 0,153 & 1,000 & & & \\
\hline 10 & Satış Büyümesi & 0,173 & 0,395 & 3,305 & 0,015 & $-0,010$ & 0,006 & 0,044 & 0,181 & $-0,008$ & 0,011 & 0,025 & 0,068 & 1,000 & & \\
\hline 11 & Likidite & 0,031 & 0,046 & 0,052 & 0,015 & $-0,220$ & $-0,034$ & $-0,012$ & $-0,028$ & 0,059 & $-0,001$ & $-0,009$ & $-0,068$ & 0,000 & 1,000 & \\
\hline 12 & FD/FAVÖK & 6,81 & 11,74 & 577,50 & $-0,010$ & $-0,004$ & 0,004 & $-0,003$ & $-0,001$ & $-0,018$ & $-0,001$ & $-0,001$ & 0,002 & 0,031 & 0,035 & 1,000 \\
\hline
\end{tabular}

Korelasyon matrisinde bağımsız değişkenler arasında önemli bir ilişkinin bulunmadığı gözlenmektedir. Değişkenlerin modelde istatistiki olarak anlamlı olması önem seviyede multicollinearity probleminin bulunmadığına işaret ederken korelasyonun tehlikeli seviyenin oldukça altında kalması da bu durumu teyit etmektedir.

\section{METODOLOJi VE AMPIRIK BULGULAR}

Arellano ve Bond (1991) tarafından geliştirilen GMM, hata terimlerinin yapısını dikkate aldığı için hata terimleri otokorelasyonlu olduğunda kullanılan bir yöntemdir. GMM, otokorelasyon olması durumunun yanısıra hem sabit hem de değişen varyans problemini çözmede de uygun bir yöntemdir (Güriş, 2015; 95). Genelleştirilmiş Momentler Metodu'nda birinci fark modeli, araç değişkeni matrisi kullanılarak dönüştürülmekte ve daha sonra bu dönüştürülmüş model Genelleştirilmiş En Küçük Kareler Yöntemi ile tahmin edilmektedir. Elde edilen tahminciler Genelleştirilmiş Momentler Tahmincileri veya iki Aşamalı Araç Değiş̧kenler Tahmincisi olarak adlandırılır (Tatoğlu, 2013; 80-81).

Genel araç değişkenli birinci farklar modeli matrislerle,

$Z^{\prime} \Delta Y=Z^{\prime} \Delta Y_{-1} \gamma+Z^{\prime} \Delta X \beta+Z^{\prime} \Delta u$

ya da,

$Z^{\prime} \Delta Y=\delta Z^{\prime} \Delta X+Z^{\prime} \Delta u \quad \Delta X=\left[\left(Y_{i t-1}-Y_{i t-2}\right),\left(\mathrm{X}_{i t}-X_{i t-1}\right)\right]$

Şeklinde gösterilebilmektedir. GMM tahmincileri ise,

$\hat{\delta}_{G M M}=\left(\Delta X^{\prime} Z\left(Z^{\prime} \hat{\Omega} Z\right)^{-1} Z^{\prime} \Delta X\right)^{-1}\left(\Delta X^{\prime} Z\left(Z^{\prime} \hat{\Omega} Z\right)^{-1} Z^{\prime} \Delta Y\right)$

olarak elde edilir. Burada, $\hat{\Omega}$ hata terimlerinin varyans-kovaryans matrisidir. Bu matris fark denkleminden elde edilen hata terimleri yardımıyla bulunur.

Tüm regresyonlar GMM ile çalıştırılmış ve yansız ve tutarlı katsayılar elde edilmiştir. GMM modellerinde 3 önemli test ön plana çıkmaktadır. Bunlardan ilki modelin genel olarak anlamlıı̆ını ölçen Wald testtir. Wald teste göre tüm katsayıların aynı anda sıfır olma olasıı̆ı̆ı yoktur. Bu durum modellerin genel anlamda makul olduğu anlamına gelmektedir. Arellano-Bond test modeldeki otokorelasyonu ölçmektedir. Teoriye göre birinci derecede tüm GMM modellerinde negatif otokorelasyonun gerçekleşmesi beklenirken ikinci derecede otokorelasyonun bulunmaması gerekmektedir. Her iki modelde de birinci dereceden negatif otokorelasyon gözlemlense de ikinci derecede herhangi bir otokorelasyon ortaya çıkmamıştır. GMM, modellerde araç değişkenler kullandığı için söz konusu değişkenlerin içsellik probleminin çözümünde yeterli olup olmadığının test edilmesi gerekmektedir. Tüm modellerde Sargan testin \%5'in üzerinde çıkması kullanılan araç değişkenlerin hata terimi ile ilişkili olmadığı halde modeldeki bağımsı değişkenlerle yeterli derecede ilişkili olduğu şeklinde yorumlanabilir. Bu durum modelde hata teriminde gizlenen ve modele doğrudan girmeyen değişkenlerden kaynaklanabilecek içsellik problemini çözmektedir. 
Tablo 3'e baktığımızda yıllık hisse getirilerinin ilk modelde \%84 güven aralı̆̆ında ikinci modelde ise \%95 güven aralığında istatistiki olarak anlamlı bir şekilde geçmiş verilerinden negatif yönlü etkilendiği görülmektedir. Başka bir deyişle diğer tüm faktörler sabitken ortalamada geçtiğimiz yıl 1 birim yükselen endeksin içinde bulunduğumuz yılda ilk modele göre yaklaşık 0,20 birim gerilemesi beklenmektedir. Bu durum endeks getirilerinin bir önceki yıla göre ters hareket etme eğiliminde olduğu anlamına gelmektedir. Yükselen piyasaların düşme, düşen piyasaların yükselme eğiliminde olması söz konusu durumu desteklemektedir. Ayrıca Borsa İstanbul için yatırımcılar ve piyasa profesyonelleri için tek yıl-çift yıl kavramının yerleşmiş olması elde edilen sonucu teyit etmektedir.

Temettü verimi tüm modellerde yüksek anlamlıııta pozitif yönlü bir şekilde yıllık hisse getirilerini etkilemektedir. Temettü verimi modele getirilerin içinde bulunduğu yıl için değil; bir yıl sonraki verileri ile eklenmiştir. Böylece beklenen temettü verimi ve beklenen karlılığın cari dönemde hisse getirisine etkisi ölçülmeye çalışılmıştır. Temettü veriminin yüksek katsayısı önemli bir algıyı tersine çevirmektedir. ABD gibi gelişmiş ülkelerde şirketler, her çeyrek temettü dağıtmaktadır. Zira şirketler, yüksek nakit üretmekte ve büyüme olanakları sınırlı olduğu için fazla nakitleri ile ya temettü dağıtmakta ya da hisse geri alımı yapmaktadırlar. Gelişmekte olan ekonomilerde ise yatırım fırsatlarının henüz doygunluğa ulaşmaması, temettü dağıtmaktansa yatıım yapılması gerektiği gibi bir algıyı beraberinde getirmektedir. Ayrıca temettü dağıtıldığında yatırımcılar \%15 stopaj ödemekte ve hissenin değer artışından kaynaklanan etkiyi yatırımcılar temettü olarak aldıklarında aynı oranda bir portföye sahip olamamaktadırlar. Zira hisse satış karına herhangi bir vergi uygulanmamaktadır. Buna rağmen Türk hisse senedi piyasası için temettünün getirilerde yadsınamaz bir etkisi olduğu görülmektedir. Elde ettiğimiz sonucu iki şekilde yorumlamaktayız; Borsa İstanbul'da temettü dağıtan şirketler, genelde belirli bir büyüklüğü aşmış ve yatırımcılarına sürekli bilgilendirme yapan kurumsal firmalardır. Bu durum temettü verimi değişkeninin kısmen büyüklük etkisini de bünyesinde barındırdığı şeklinde yorumlanabilir. Böylece Türk borsasında ortalamada yüksek getiri sağlayan hisse senetlerinin genelde büyük şirketlere ait olduğu sonucuna ulaşabiliriz. Ayrıca temettü verimi bir yıl sonraki veri olarak modelde yer aldığı için aslında şirketlerin bir yıl sonraki beklenen karları hakkında da bilgi vermektedir. Başka bir deyişle katsayı, bir yıl sonra karı artacak olan ya da karının artma beklentisi yüksek olan hisse senetlerinin getirisi oldukça yüksek olabiliyor şeklinde yorumlanabilir. Katsayıdaki yüksekliğin bir diğer sebebi ise temettü veriminin hesaplanma biçimi ve rakamsal boyutudur.

Birinci modelde görece daha düşük FD/FAVÖK; ikinci modelde ise görece daha düşük F/K hisse getirisi üzerinde baskındır. Ancak katsayılara bakıldığında her iki değişkenin çok benzer oranda getiri üzerinde etkili olduğu görülmektedir. Bu durum bir başka kavram açısından önemlidir. Piyasada genel olarak FD/FAVÖK daha itibarlı bir oran gibi algılanmasına rağmen çalışmamızın sonuçları F/K 'nın da FD/FAVÖK kadar etkili olduğu anlamına gelmektedir. F/K 1930 yılından buyana pratik ve algılaması kolay olduğu için bireysel yatırımcılar tarafından en çok kullanılan oranlardan biri olması elde edilen sonucu desteklemektedir. Türk piyasası için F/K 'nın en büyük zorluğu, net karı dikkate aldığı için kurdaki hareketlenmeler nedeniyle FD/FAVÖK 'e göre daha fazla dalgalanmasıdır. Birçok şirketin yatırımlarına göre makul boyutta kar açıklayamaması ya da zarar etmesi FD/FAVÖK 'ün tercih edilmesini beraberinde getirmektedir. Ayrıca şirketlerin değişen kaldıraç seviyeleri ve farklı amortisman politikaları nedeniyle net dönem karının ölçülmesinin tüm örneklem için aynı standartta gerçekleşmemesi F/K kullanımının zorlukları arasında yer almaktadır. Buna rağmen modelimiz yüksek FAVÖK açıkladığı halde düşük net kar ya da zarar açıklayan şirketlerin hisse getirilerinin bu durumdan olumsuz etkilendiği sonucuna ulaşmıştır. Bununla birlikte her iki çarpanın katsayısının tüm modellerde negatif olması çarpanlar geriledikçe hisse getirilerinin arttığı anlamına gelmektedir. Ayrıca hisse getirileri yılsonu kapanış ve yılbaşı açılışlara göre 1 yıllık vadede hesaplanırken piyasa çarpanları getirilerin hesaplandığı yııın ilk çeyreğindeki çarpanlardır. Bu durum yııın başındaki piyasa çarpanlarına göre yatırımcıların gelecek beklenti getirilerinin oluştuğu anlamına geldiği gibi piyasa oyuncularının hisse yatırımını uzun vadeli bir yatırım gibi gördüğü şeklinde de yorumlanabilir.

Jeopolitik risklerin artması halinde hisse getirileri, diğer faktörler sabitken ortalamada gerilemektedir. Söz konusu belirsizlikteki etkinin piyasa çarpanlarından daha fazla olduğu dikkat çekicidir. Başka bir deyişle çarpanlardaki 1 birimlik gerilemenin getiri üzerindeki etkisi jeopolitik risklerdeki 1 birimlik azalmanın etkisinden daha düşüktür. Bu durum hisse fiyatlamasında belirsizliklerin azalmasının oldukça önemli olduğu anlamına gelmektedir. Belirsizliklerin azaldığı bir ortamda yüksek gibi gözüken piyasa çarpanı aslında yatırımcılar tarafından sanıldığı kadar yüksek görülmemektedir. Avrupa, Suriye, Rusya ve Ortadoğu gibi Türk şirketlerinin ihracat bölgelerindeki olumsuz gelişmeler şirket karlarını negatif yönde etkileyeceği için böyle bir etki, kendini mali verilerde görülmeden hisse fiyatlamasında baskın bir şekilde ortaya çıkarmaktadır.

Yıl içerisindeki yatırım haberleri ve gerçekleşmelerinin aynı yıl içerisindeki hisse getirisinde önemli bir etkiye sahip olduğunu gözlemekteyiz. Tüm yatırımların benzer bir etkiye sahip olması beklenemez. Zira bazı şirketlerin yatırım yaptıkları halde aktifleri gerilemektedir. Yatırım/Amortisman oranı $1 x^{\prime}$ in üzerindeki şirketler idame yatırımlarından ziyade beklenti yaratan yatırımlar gerçekleştirmektedir. Modelde yatıım oranının pozitif etkisinin söz konusu şirketlerden kaynaklandığını öngörmekle birlikte bu durumu test eden bir çalışma gerçekleştirilmemiştir.

Şirketlerin yüksek kaldıraç seviyeleri finansal borçluluk derecelerinin artması olarak yorumlanmaktadır. Model sonuçlarına göre kaldıraç seviyesinin istatistiki olarak anlamlı bir şekilde hisse getirisi üzerinde etkili olmadığını görmekteyiz. Bazı 
şirketler, yüksek kaldıraç seviyeleri ile iflas etme riski ile karşı karşıya kalabilir ki bu durum yatırımcıları söz konusu şirketlerin hisse senedi yatırımlarından uzaklaştırır. Ancak bazı sektörlerde yüksek borçluluk önemli beklentileri de beraberinde getirmektedir. Enerji sektöründe AK enerji, Zorlu Enerji ve Aksa Enerji gibi yüksek itibarlı şirketler beklenti doğuran yatırımlar yaptıkları için yüksek kaldıraç oranına sahiptirler. Ayrıca Türk borsasının en yüksek kaldıraç seviyesindeki şirketlerinden biri Türk Hava Yolları'dır. Bu durum yüksek kaldıraç seviyesinin etkisini verilerin modellenmesinde belirsiz bırakmaktadır. Bazı şirketler için yüksek kaldıraç olumsuz beklentiler nedeniyle hisse getirisini düşürürken diğer şirketler için ise hisse getirilerini artırmakta ve bu iki etki ortalamada birbirini yok etmektedir. Yine de her iki modelde de kaldıracın etkisi negatif çıkmıştır. Bu veri istatistiki olarak anlamlı olsaydı bile kaldıraç oranına yatırım oranı ile birlikte bakmak gerekecekti. Her iki oranın toplamının hala pozitif olması borçluluk artışı ile yapılan yatırımların nette hisse senedi getirilerini pozitif etkilediği anlamına gelmektedir.

Şirketlerin Tobin q değeri oranları literatürde firmaların stratejik varlıkları ya da maddi olmayan varlıklarının piyasa değerinin önemli bir göstergesi olarak kabul edilmektedir. Şirketlerin gizli değerlerinin ölçümü için henüz genel kabul görmüş bir metot bulunmasa da Tobin q bu işlev için kullanılabilmektedir. Model sonuçlarına göre şirketlerin stratejik varlıkları ya da maddi olmayan yatırımları ortalamada diğer tüm faktörler sabitken hisse getirisi üzerinde olumsuz bir etkiye sahiptir. Söz konusu veri Türk şirketleri için ortalamada bir sonuç olup bu durum bazı şirketlerin gerçekleştirdikleri maddi olmayan yatırımları ile hisse getirilerini artırmadığı anlamına gelmez. Maddi olmayan yatırımlar AR-GE, marka harcamaları, kurumsalık, patent, stratejik personel ve teknoloji yatırımlarını içerdiği için doğası gereği riskli yatırımlardır. Bu yatırımların doğru yönetilememesi söz konusu yatırımların giderlerine göre beklenen gelirlerin oluşmasını engelleyebilir. Katsayının eksi (negatif) çıkması yatırımcılar nezdinde ortalamada Türk şirketlerinin somut olmayan yatırımlarının yeterli düzeyde karlılık yaratacak nitelikte olmadığı şeklinde yorumlanabilir.

Ülke riskini ölçme amaçlı modele gösterge tahvil faizi eklenmiştir. Gösterge tahvil faizinin artması ilk modelde \%90 güven aralığında istatistiki olarak anlamlı bir şekilde hisse getirilerini azaltmıştır. Tahvil faizleri ülke riskine ek olarak bünyesinde enflasyonu da barındırmaktadır. Artan enflasyonun tüm emtialarla birlikte hisse senedi üzerine de pozitif bir etkisinin olması beklenebilir. Bu durum gösterge tahvilin bünyesinde barındırdığı farklı dinamiklerin hisse getirisini farklı açılardan etkilediği anlamına gelse de tüm etkilerin netinde ilişki negatife dönmektedir. Ancak söz konusu farklı dinamikler negatif ilişkinin gücünü kısmen azaltabilir. İkinci modelde katsayının anlamlı olmaması da yorumumuzu desteklemektedir.

Her iki modele göre de şirketlerin yıl içerisindeki satış büyümesi yıllık hisse getirilerini pozitif etkilemektedir. Şirket yüksek kar açıklasa bile net satışlarını artıramayan bir şirketin mevcut rekabet ortamında yok olması kaçınılmazdır. Bu durum Türk şirketlerinin karlılık önceliğini ikinci plana atmasının en büyük nedenidir. Birçok şirket ilk olarak pazar kapma ve net satışlarını artırmaya odaklanmakta sonrasında maliyet optimizasyonuna yönelerek karııı̆ını artırmaktadır. Şirketlerin politikalarının hisse senedi getirileri üzerinde de pozitif bir algı oluşturduğu model sonuçlarından anlaşılmaktadır.

Şirketlerinin hisse senetlerinin yıl içerisindeki günlük getirilerinin standart sapması modele şirkete özgü riski ölçmek amacıyla eklenmiştir. Gösterge tahvil faizindeki artıştan çok daha fazla oranda şirketlere özgü risklerin hisse getirisini negatif etkilediğini gözlemlemekteyiz. Gösterge tahvil faizi global anlamda ülkedeki riskin hisse getirisine etkisini ölçerken söz konusu negatif etki tüm şirketlere aynı oranda yansımamaktadır. Şirkete özgü riskler ülke risklerinden farklılaşabilmektedir. GSYiH büyümesinin beklentinin altında gerçekleşmesi ya da siyasi-politik risklerin artması hisse senetleri getirisini aşağı yönlü çekebilmektedir. Şirketlere özgü riskler, şirketlerin yanlış yatırımları, yöneticilerin karar alma süreçlerinin bozulması ya da şirketin hammadde giderlerinin beklentiden daha kötü gerçekleşmesi olarak örneklendirilebilir. Bu faktörlerin hisse getirileri üzerinde daha olumsuz bir etkisi olduğunu gözlemlemekteyiz. Söz konusu katsayının başka bir yorumu da olabilir; Bilindiği üzere portföy teorisine göre belirli sayıdaki hisse senedi ile şirketlere özgü riskler ortadan kaldırılabilmektedir. Katsayıdaki keskin negatiflik özellikle bireysel yatırımcıların portföy yatırımı geleneklerinin olmamasından da kaynaklanabilir. Zira kurumsal yatırımcılar şirketlere özgü risklerin arttığı bir ortamda portföylerinde bu etkinin ortadan kaldıııması nedeniyle satışa gerek kalmadan portföy getirisinin azalmasını engelliyor olabilirler. Ancak portföy yatırımı yapmadıkları için şirkete özgü risklerden korkan bireysel yatırımcıların söz konusu risklerin arttığı ortamda hisse senetlerini satarak katsayının negatif çıkmasında etkili olduğunu düşünmekteyiz.

Modelimize göre hisse senetlerinin likiditesi arttıkça keskin bir şekilde hisse senedi getirileri yükselmektedir. Alındığında satılamayan bir mala olan ilginin düşmesi son derece makuldür. Katsayının temettü verimi kadar yüksek olması Türk borsası için likiditenin oldukça önemli olduğu şeklinde yorumlanabilir. Başka bir deyişle bir şirket önemli derecede karlılıklar açıklasa bile eğer hisse senedi tahtası yeteri kadar likit değilse yatırımcılar hisse senedine ilgi duymamaktadır. Bu durum Türk şirketlerinin yöneticileri için önemli bir politikayı ön plana çıkarmaktadır. Şirketlerin borsa değeri ana ortaklar için bir itibar göstergesidir. Hisse senedi değerlendikçe şirketlerin bağımsız denetçiler, tedarikçiler, bankalar, müşteriler ve çalışanları karşısında itibari artmaktadır. Şirketler, değerli hisse senetlerini bankalara teminat gösterip daha ucuz maliyetli kredi kullanabilmektedir. Ayrıca firmalar, değerli hisse senetleri ile başka bir şirketin hisse senetlerini satın alabilmekte ve birleşme gerçekleştirebilmektedirler. Bu durum şirketlerin borsa değerinin yüksek olmasının temel politikalar arasında yer alması gerektiği anlamına gelmektedir. Model çıktılarımız şırket değerini artırmak için mali tablolardaki iyileşmenin yeterli 
olmadığı sonucuna ulaşmaktadır. Dolayısıyla şirketler, stratejik hedefleri arasına hisse senetlerinin işlem hacmini artırmayı da eklemelidirler. Halka açık kısmın düşük olması halinde söz konusu oranın artırılması ya da likidite sağlayıcılık işlemleri ile hisse tahtasında alıcı ve satıcı konumunda yer alarak yatıımcıların likiditelerini artırmaları halinde şirketler, piyasa değerlerini artırabilir ve değer artışını kendi faaliyetlerinde bir kaldıraç olarak kullanabilirler. Burada bir başka yoruma da ulaşmaktayız. Likiditedeki artışın mı hisse değerini artırdığı; yoksa hisse değerindeki artışın mı likiditeyi artırdığı tartışmalı bir konudur. Her ne kadar işlem hacmi yüksek şirketlerin kolay alınıp satılmaları ve likidite iskontolarının düşük olmaları nedeniyle likiditesi düşük şirketlere göre daha yüksek getiri vaat etmeleri sezgisel olarak doğru görülse de yine de çalışmayı daha öteye taşımak ve denklemi daha doğru yorumlamak adına ileriki çalışmalarda hisse getirisi ve likidite arasındaki Granger Nedensellik ölçümü gerçekleştirilebilir.

Çalışmamızın son çıktısı ise FD/FAVÖK ve $F / K$ değişkenlerinin eşanlı etkisini ölçen çarpım değişkenidir. Bu değişkeninin katsayısının pozitif çıkması önemli bir sonuç olarak değerlendirilmektedir. Söz konusu değişken, piyasada sadece $F / K$ ya da sadece FD/FAVÖK'ün etkili olmadığı ve Türk borsasındaki yatırımcıların her iki değişkeni de dikkate aldığı şeklinde yorumlanmaktadır. FD/FAVÖK'teki bir birimlik azalmanın hisse getirisini artırdığını sadece FD/FAVÖK değişkenine baktığımızda anlamaktayız. Ancak aynı dönemde aynı şirketin F/K'sındaki artış, hisse senedi getirisinin FD/FAVÖK değişkenine olan hassasiyetini azaltmaktadır. Bir örnekle açıklamak gerekirse 1 yıl önce 5x FD/FAVÖK çarpanına sahip bir şirketin bir yıl sonra 4x FD/FAVÖK çarpanına sahip olması sadece bu değişime bakıldığında hisse getirisinin artması gerektiği şeklinde yorumlanabilir. Ancak aynı şirketin aynı dönemlerde F/K'sı 6x seviyesinden 7x'ye çıkmışsa FD/FAVÖK'teki düşüşten kaynaklanan beklenen getirideki artışın etkisi azalmaktadır. Hatta $F / K^{\prime}$ daki artış çok daha yüksekse Türk piyasasındaki yatırımcılar için FD/FAVÖK'teki gerileme önemli bir anlam ifade etmemekte ve söz konusu şirket için "ucuz kalmış" yorumu yapılamamaktadır. GMM bu durumu verilerden net bir şekilde çıkarabilmektedir.

Tablo 3: Piyasa çarpanları ve Kontrol Değişkenlerin Hisse Getirisine Etkisi, 1998-2014

Bağımlı Değişkenler

Hisse Getirisi (HG)

HG(-1)

Temettü Verimi(1)

FD/FAVÖK

F/K

JPR Türkiye

Yatırım

Kaldıraç

PD/DD

Tobin Q

Tahvil

Satış Büyümesi

Standart Sapma

Likidite

FD/FAVÖK*F/K
$42.727^{* * *}$

$-0.00015^{* * *}$

$-0.00013^{* * *}$

$-0.012^{* * *}$

$4.739 * * *$

$-0.096$

$0.00092^{* * *}$

$-0.590 * * *$

$-0.425 *$

$0.117^{* * *}$

$-28.439 * * *$

$31.500 * * *$
Hisse Getirisi (HG)

$-0.029 * *$

$40.150 * * *$

$-8.31 \mathrm{E}-05^{* *}$

$-0.00044^{* * *}$

$-0.012 * * *$

$4.220 * * *$

$-0.094$

$0.00123 * * *$

$-0.619 * * *$

0.005

$0.146^{* * *}$

$-28.253^{* * *}$

32.151***

$1.60 \mathrm{E}-05^{* * *}$

\begin{tabular}{lcc}
\hline Birey Kesitler & 172 & 172 \\
\hline Periyot Sayısı & 14 & 14 \\
\hline Gözlem Sayısı & 1.962 & 1.962 \\
\hline AR(1) Olasılık Değeri & 0.0186 & 0.0125 \\
AR(2) Olasılık Değeri & 0.3815 & 0.2839 \\
\hline Sargan Test Olasılık Değeri & 0.1519 & 0.1291 \\
\hline Wald Test Olasılık Değeri & 0.00 & 0.00
\end{tabular}

Not: Tüm regresyonlar birinci dereceden farklara dayalı dinamik panel GMM istatistiki metodu ile çözümlenmiştir. Değişkenler: HG = Hisse Yıllık Getiri, FD/FAVÖK = Firma Değeri/FAVÖK, F/K = Piyasa Değeri/Net Kar, JPR Türkiye = Türkiye Jeopolitik Risk Endeksi, PD/DD = Piyasa 
Değeri/Defter Değeri, q = Tobin q, Tahvil = Gösterge Tahvil Faizi. Yıldızlar 1\%, 5\%, ve 10\% önemlilik derecesinde istatistiki olarak anlamlılık derecesini kategorize etmektedir. Tüm regresyonlar GMM'in gerekli testlerinde başarılı sonuçlar elde etmiştir.

\section{SONUÇ}

Hisse senedi getirilerinin modellenmesi son dönemde önemi artan çalışmalar arasında yer almaktadır. Levine (1996), yaptığı çalışmada hisse senedi getirisi ile ülke ekonomik büyümeleri arasında pozitif bir ilişki bulmuştur. Bu durum merkez bankalarının stratejik hedefleri arasında hisse senedi piyasalarını da dikkate alması gerektiği görüşünü desteklemektedir. $A B D^{\prime}$ de siyasetçilerin yaptığı açıklamaların borsaların kapanışlarını dikkate alması ve borsalarda önemli gerilemeler gözlendiğinde hükümet ya da FED'in müdahaleleri aynı zamanda piyasalardaki düşüşün makro sonuçlar da doğurmasından kaynaklanmaktadır.

Yaptığımız çalışmada hisse senedi getiri modellemesini Türkiye örneği üzerinden oluşturmak istedik. Beklendiği gibi hisse senedi getirileri bir önceki yılki getirilerinin tersine bir eğilim içerisinde yer almaktadır. Yılbaşında F/K ve FD/FAVÖK'ü daha düşük hisse senetlerinin yılsonundaki getirileri daha yüksek olmaktadır. Modelin sonuçlarına göre piyasa, hisse senetlerini fiyatlarken tek bir çarpana bakmamakta; F/K ve FD/FAVÖK çarpanlarını neredeyse eşit önemlilik derecesinde dikkate almaktadır. Yılbaşındaki çarpanlarına göre yılsonu getirilerin oluşması yatırımcıların yaklaşık 1 yıla yakın bir vadede hareket ettiklerine de işaret etmektedir.

Temettü verimi beklentisi arttıkça hisse senetlerinin getirisi önemli oranda yükselmektedir. Bu durum Türk piyasasında temettü veriminin mevcut algının aksine hisse senedi getirisi üzerinde güçlü bir etkiye sahip olduğunu göstermektedir. Şirket değerini artırmak isteyen ana ortakların bir temettü politikası oluşturması ve yatırımcıları ile paylaşması gerekmektedir. Dağıtılan temettüden vergi ödenmesine ya da bazı yatırımların gerçekleşmesini önleme potansiyeline rağmen Türk piyasası yatırımcıları, az da olsa temettü dağıtan şirketleri tercih etmektedir.

Şirketlerin kaldıraç seviyelerinin hisse getirisinde ortalamada önemli bir etkiye sahip olmadığı görülürken satış büyümesinin getirileri yukarı yönlü artırdığı sonucuna ulaşılmıştır.

Jeopolitik riskler, ülke riski ve şirkete özgü riskler hisse senedi getirilerini negatif etkilerken şirkete özgü risklerin daha baskın olduğu görülmektedir. Özellikle bireysel yatırımcıların portföy yatırımı gerçekleştirmemesi şirkete özgü risklerin hisse senedi getirisindeki olumsuz etkisinin önemli bir sebebi olabilir. Zira portföy yatırımı yapan kurumsal yatırımcılar şirkete özgü riskleri yok edilebilmektedir.

Şirketlerin yıl içerisinde gerçekleştirdikleri sabit sermaye yatırımları hisse senedi getirisini artırırken kaldıraç seviyelerinin getiride ortalamada net bir etkisi görülememiştir. Şirketlerin maddi olmayan yatırımları ise yeterli nitelikte olmaması ve riskli olmaları nedeniyle hisse senedi getirisinde beklenen etkiye sahip değildir.

Hisse senetlerinin likiditesi arttıkça getirilerinin önemli bir oranda yükseldiği görülmektedir. Gelecekte şirketlerin piyasa değeri ana ortaklar için daha stratejik olacaktır. ABD'de olduğu gibi hisse senetleri banka kredileri için teminat olarak kullanılabilecek, şirket satın almalarında takas görevi görebilecek, çalışanlara prim veya bonus olarak verilebilecek, tahvil anapara ödemelerinde bir opsiyon olarak kullanılabilecektir. Bu durum şirket yöneticileri için sadece FAVÖK ya da Net Karın değil şirket değerinin de belirli bir hedefe konulması anlamına gelecektir. Bu şartlar altında şirketlerin likidite sağlayıcılık işlemleri ya da halka açıklık oranını artırarak şirket değerini yükseltmesi gerekecektir. ABD'de şirketlerin halka açıklık seviyeleri \%80'leri aşabilmektedir.

Çalışmamızda gösterge tahvilin toplam etkisi dikkate alınmıştır. Gösterge tahvilin enflasyon etkisi arındırılarak modele eklenmesi halinde ise ülke riskinin hisse senedi getirisine etkisi daha net bir şekilde gözlemlenebilir. Modelimiz likiditenin hisse getirisine etkisini ölçmekle birlikte Granger Nedensellik ile etkinin yönünün netleştirilmesi likiditenin daha doğru yorumlanabilmesini beraberinde getirebilir.

\section{KAYNAKÇA}

Aktaş, R. ve Karan, M. Baha. (2000), “Predicting Stock Returns Using Fundamantal Information and Multivariate Statistical Modelling: An Emprical Study on Istanbul Stock Excahange”, Hacettepe Üniversitesi IiBF Dergisi, Cilt.18, Sayı. 2, ss. 433-449.

Arellano, M. ve Bond, S. (1991), "Some Tests of Specification for Panel Data: Monte Carlo Evidence and an Application to Employment Equations", Review of Economic Studies, 277-297.

Baltagi, B. (2005). Econometric Analysis of Panel Data. Chicester, England: John Wiley and Sons Press.

Basu, S. (1977), "Investment Performance of Common Stocks in Relation to Teir Price-Earnings Ratios: A Test of Te Efficient Market Hypothesis", The Journal of Finance, vol. 32, no. 3, pp. 663-682. 
Batchelor, R. ve Orakcıoğlu, I. (2003), "Event-Related Garch: The Impact of Stock Dividends in Turkey", Applied Financial Economics, vol. 13, no. 4, pp. 295-307.

Campbell, J. Y. ve Shiller, R. (1988). "Stock Prices, Earnings and Expected Dividends", Journal of Finance, vol. 43, pp. 661-676.

Canbaş, S., Düzakın, H. ve Kılıç, S.B., (2002), "Fundamental and Macroeconomic Information for Common Stock Valuation: The Turkish Case", Yapı Kredi Economic Review, vol. 13, no. 1, pp. 55-64.

Chang, H-L., Chen, Y. S., Su, C. W. \& Chang, Y. W. (2008). “The Relationship between Stock Price and EPS: Evidence Based on Taiwan Panel Data", Economics Bulletin, vol. 3, no. 30, pp. 1-12.

Dehaun, J. ve Jin, Z. (2008), “Firm Performance and Stock Returns: An Empirical Study of the Top Performing Stocks Listed on Shanghai Stock Exchange", Academy of Accounting and Financial Studies Journal, vol. 12, no. 1, pp. 79-85.

Demir, A., Küçükkiremitçi, O., Pekkaya, S. ve Üreten, A. (1997), IMKB'de Sanayi Şirketlerinin Hisse Senedi Getirileri ile Finansal Oranları Arasındaki İlişkilerin Belirlenmesi ve Bu illişkilere Göre Şirketlerin Sıralandırılması (1992-93-94 Yılları İçin Bir Uygulama), SPK Yayın No: 56.

Ege, İ. ve Bayrakdaroğlu, A. (2009), "An Analysis of the Performance of ISE Companies Stock Yields Using The Logistic Regression Method", ZKU Journal of Social Sciences, vol. 5, no. 10, pp. 139-158.

Günalp, B., Kadıoğlu, E ve Kılıç, S. (2010), “Nakit Temettü Bilgisinin Hisse Senedi Getirisi Üzerinde Önemli Bir Etkisi Olup Olmadığının IMKB'de Test Edilmesi”, Hacettepe Üniversitesi İktisadi ve İdari Bilimler Dergisi, Cilt. 28, Sayı. 2, ss. 47-69.

Güriş, S. (2015). Stata ile Panel Veri Modelleri İstanbul: Der Yayınları.

Habib, Y. Zernigah, I.K. ve Muhammad A.K. (2012), “Dividend Policy and Share Price Volatility: Evidence from Pakistan" Global Journal of Management And Business Research, vol. 12, no. 5, pp. 78-84.

Holthausen, W. ve Larcker, D. (1992), "The Prediction of Stock Returns Using Financial Statement Information", Journal of Accounting and Economics, Vol.15, pp. 373-411.

Horasan, M. (2009), “Fiyat/Kazanç Oranının Hisse Senedi Getirilerine Etkisi: IMKB 30 Endeksi Üzerine Bir Uygulama”, Atatürk Üniversitesi Iktisadi ve İdari Bilimler Dergisi, Cilt 23, Sayı 1, ss. 181-192.

Karan, M. B. (1996). “Hisse Senetlerine Yapılan Yatırımların Performanslarının Fiyat/Kazanç Oranına Göre Değerlendirilmesi: İMKB Üzerine Ampirik Bir Çalışma", iktisat, İşletme ve Finans Dergisi, 11, ss. 119. 26-35.

Khan, K.I, Muhammad, A., Arslan, Q., Adeel, N. ve Maryam, I.K. (2011), “Can Dividend Decisions Affect The Stock Prices: A Case of Dividend Paying Companies of KSE", International Research Journal Of Finance and Economics, vol. 76, pp. 67-74.

Korkmaz, Ö. ve Karaca, S. S. (2013), “Firma Performansını Etkileyen Faktörler ve Türkiye Örneği”, Ege Akademik Bakış, Cilt. 13, Sayı. 2, ss. 169-179.

Levine, R. A. (1996), Stock Market Development and Long-Run Growth. World Bank Economic Review, 323-339.

Lewellen. J. (2002), "Predicting Returns with Financial Ratios”, Social Science Research Network Working Paper Series, No:4371-02.

Moderes, A, Sajjad, A ve Mozhgan M. (2008), "Testing Linear Relationships Between Excess Rate of Return and Financial Ratios", Social Science Research Network Working Paper Series, No:14.

Mukherji S., Manjeet S. D. \& Yong H. K. (1997), “A Fundamental Analysis of Korean Stock Returns”, Financial Analysts Journal, vol. 53, no. 3, pp. 75-80.

Oh K.Y, Kim B ve Kim H. (2006), "An Empirical Study of Te Relation Between Stock Price and EPS in Panel Data: Korea Case", Applied Economics, vol. 38, ss. 2361-2368.

Okafor, C.A., Mgbame, C.O ve Mgbame, A.M.C. (2011), “Dividend Policy and Share Price Volatility in Nigeria”, Jorind, vol. 9, no. 1, pp. 202210.

Omran, M ve Ragab, A. (2004), "Linear Versus Non-Linear Relationships Between Financial Ratios and Stock Returns: Emprical Evidence From Egyptian Firms", Review of Accounting and Finance, vol. 3, no. 2, pp. 84-102.

Şamiloğlu, F. (2005), “Hisse Getirileri ve Fiyatlarıyla, Kazanç ve Nakit Akımları Arasındaki i̇lişki: Deri ve Gıda Şirketlerinde Ampirik Bir Inceleme", İstanbul Üniversitesi İsletme Fakültesi Dergisi, 26, ss. 120-126.

Tatoğlu, Y.F. (2013). İleri Panel Veri Analizi-Stata Uygulamalı (2. Baskı). İstanbul: Beta Basım Yayın Dağıtım A.Ş. 


\section{EK 1: Değişken Grafikleri}
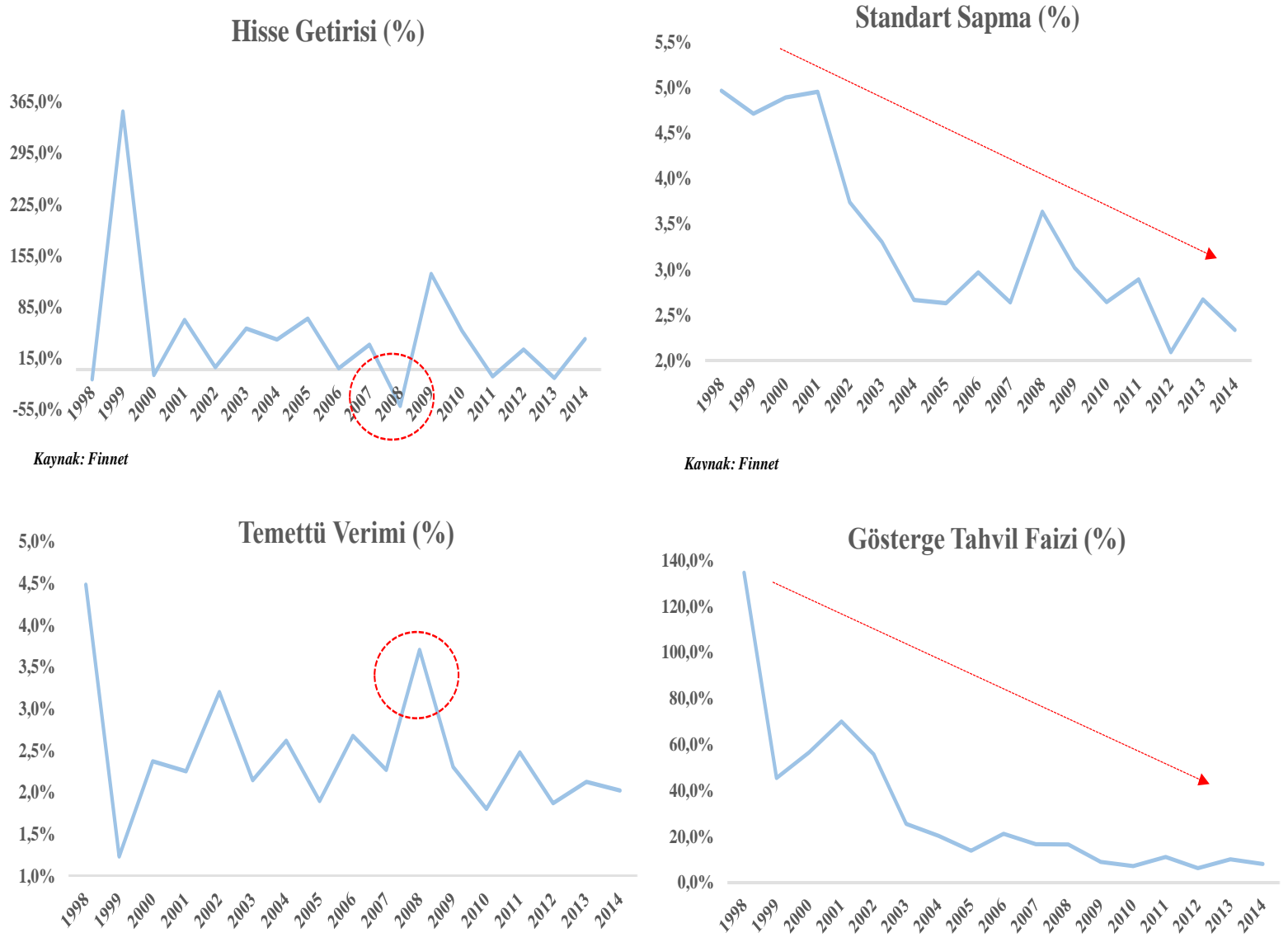

Kaynak: Finnet

Kaynak: Finnet
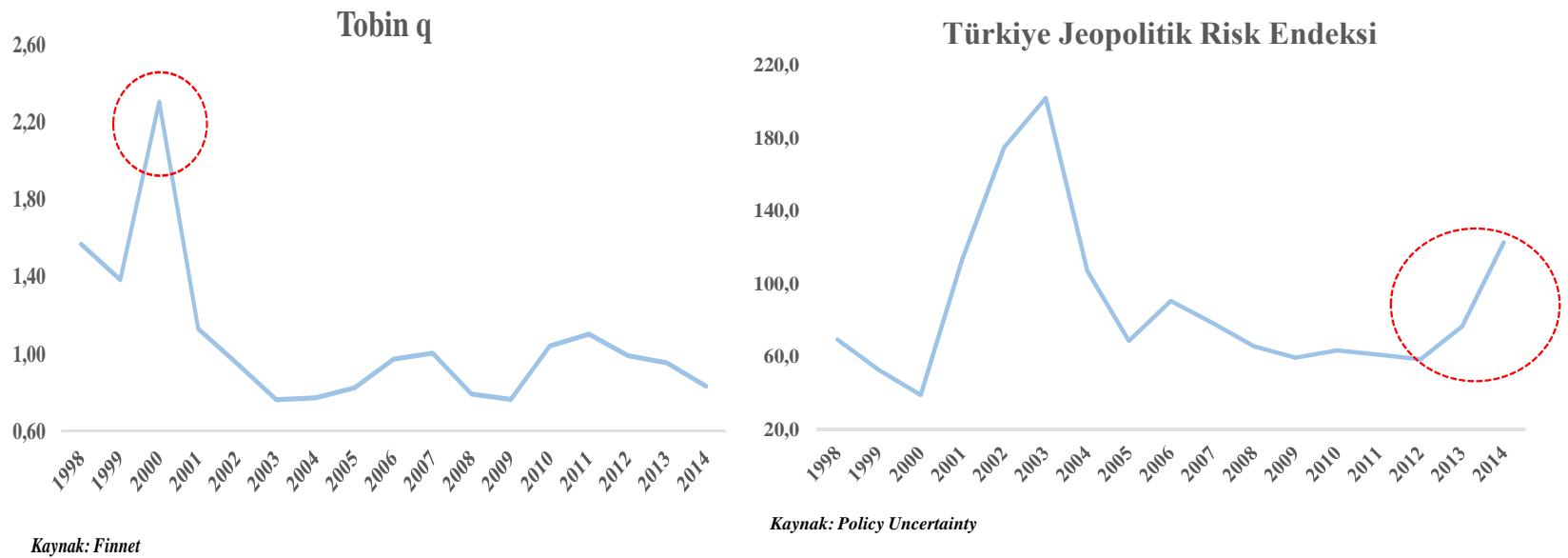

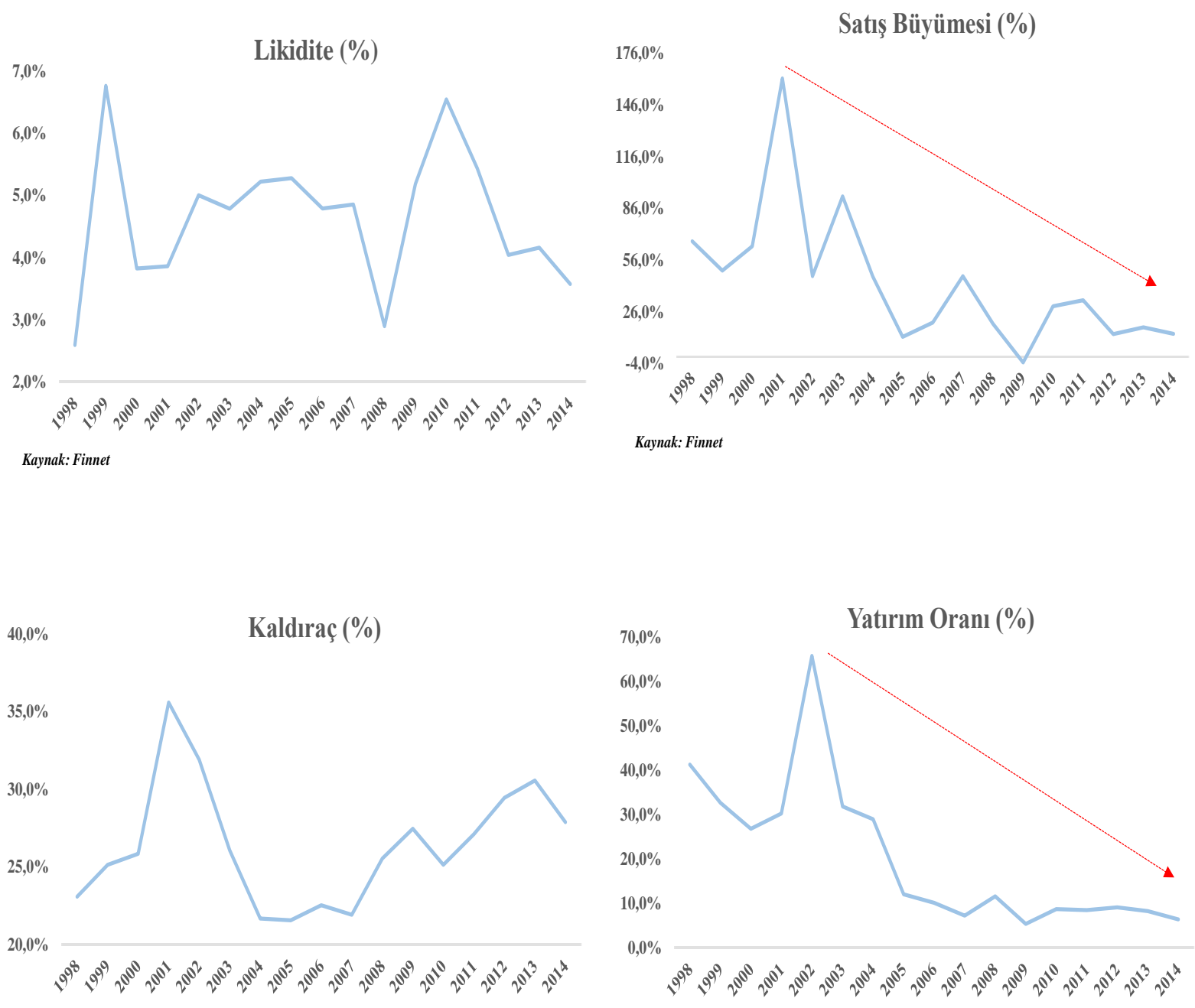

Kaynak: Finnet

Kaynak: Finnet

F/K

12,0

FD/FAVÖK
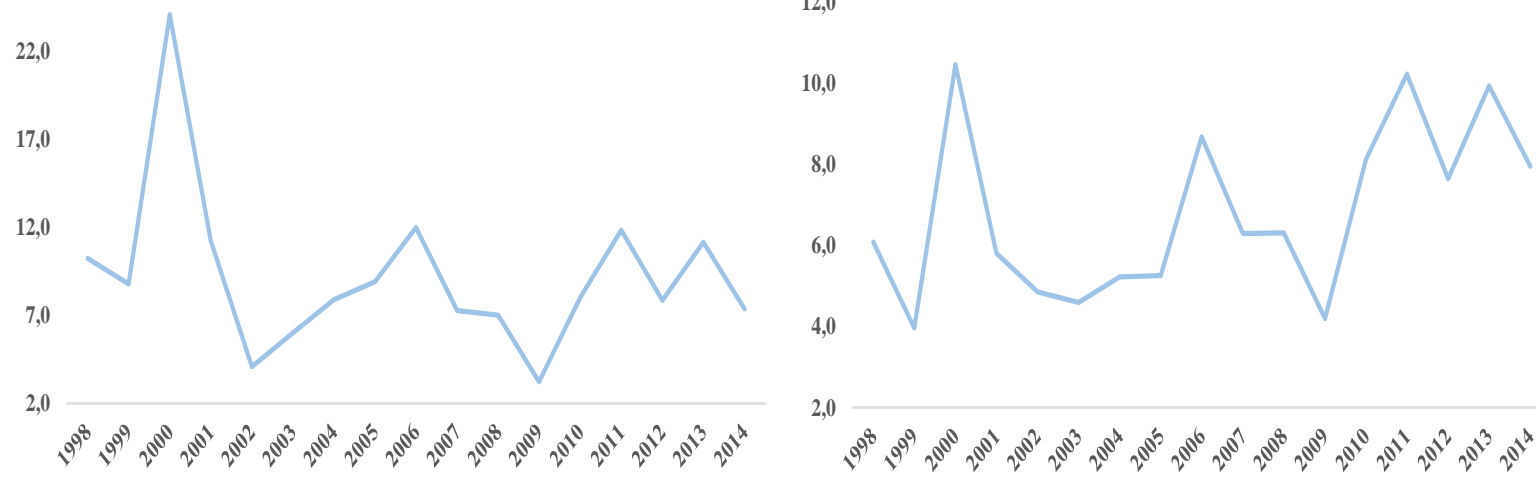

2,0

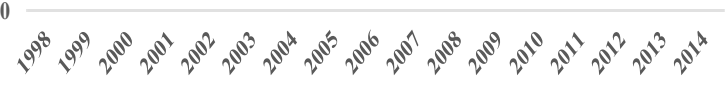
Kaynak: Finnet

Kaynak: Finnet 